\begin{abstract}
Коломієць Н. $\boldsymbol{C}$.
кандидат філологічних наук, доцент

Криворізький педагогічний інститут ДВНЗ «Криворізький національний університет»
\end{abstract}

Яременко Н. В. кандидат філологічних наук, дочент Криворізький педагогічний інститут ДВНЗ «Криворізький начіональний університет»

\title{
ХУДОЖНІЙ КОНЦЕПТ «ДИТИНСТВО» У ПОВІСТІ Р. БРЕДБЕРІ «КУЛЬБАБОВЕ ВИНО»
}

У статті вивчено спещифіку реалізачії в повісті Рея Бредбері «Кульбабове вино» художнього концепту «дитинство» як втілення авторських світоглядних пріоритетів, які формують індивідуально-авторську картину світу й систему етико-естетичних домінант письменника в досліджуваному творі.

Ключові слова: художній концепт, ментальне утворення, уява, фантазування, психологізм, ліро-епічна проза.

Статья содержит анализ особенностей реализащии в повести Рэя Брэдбери «Вино из одувачиков» художественного конщепта «детство» как воплощение авторських мировозренческих приоритетов, которые формируют индивидуально-авторскую картину мира и систему этико-эстетических доминант в изучаемом произведении.

Ключевые слова: художественный кониепт, ментальное образование, фантазия, психологизм, лиро-эпическая проза.

The article contains ananalysis ok the realization peculiarity in Ray Bradbury's novel "Dandelion Wine" ok artistic concept "childhood" as the embodiment of autor hideological priorities that form the individual author's view of the world and the system of ethical-aesthetic dominant in the studied story.

Keywords: artistic concept, mental formation, fantasy, psychologism lyric-epic prose.

Повість Р.Бредбері «Кульбабове вино» репрезентує суспільні рефлексії світу дитинства в літературі, хоча в сучасному літературознавстві Р.Бредбері, передусім, відомий як науковий фантаст. Саме під таким кутом зору його творчість вивчали І.Сиднін, 
В.Назарець, Р.Рибкін, В.Пузій, В.Скурлатов. У наукових працях С.Маркіної, А.Саллівена, М.Менгелинга та ін. осмислено притчиєвість і багатоплановість більшості творів прозаїка, зокрема проблема їх жанрової специфіки, поетики, ідейно-тематичного змісту.Так, на думкуР.Рибкіна, американського прозаїка, передусім, цікавив процес вибудови людської особистості: «митець намагався донести до читачів оригінальність та безпосередність людського мислення, індивідуальність сприйняття навколишнього світу і дорослим, і дитиною» [Рибкин, 1989: 382]. Особливу увагу привертає в цьому плані автобіографічна повість митця «Кульбабове вино».

Мета нашої розвідки полягає у вивченні повісті в аспекті специфіки реалізації в ній художнього концепту «дитинство».

Уперше застосоване в логіці,поняття «художній концепт», набуваючи значущості в системі літературознавчих дисциплін, використовується на позначення одиниці пізнання та осмислення світу. При цьому дослідниками переважно приділяється увага концептам, що характеризують авторський вибір світоглядних пріоритетів і формують індивідуально-авторську картину світу в художньому творі, яка визначається естетичними домінантами письменника. Отже, концепт як одиницяаналізу художнього твору є філософсько-естетичним феноменом, ментальним утворенням зі складною динамічною структурою, в якій відображається система поглядів, уявлень, асоціацій, переживань автора.Як багатоелементне ментальне утворення концепт містить у своїй структурі багатоплановий компонент, аналіз якого дозволяє виявити ціннісну орієнтацію митця, що у свою чергу, визначає стратегію творчості: вибір тематики та проблематики творів, адекватної художньої форми втілення авторського задуму[Коситов 2012: 1].

Дослідниками помічено, щопрозаїку більшості своїх творівпрагне осмислити процес становлення людини, проблеми, які іiі хвилюють, цінності життя, що допомагають відрізнити добро від зла, істину від неправди, світло від темряви. Повість «Кульбабове вино»Р.Бредбері міститьв опоетизованому, романтичному вигляді 
окремі факти та хронологію життя автора, має мозаїчну структуру й реалізується в ряді мікросюжетів.

Складовими художнього концепту «дитинство»в повісті $є$, передусім, образи-персонажі твору, зокрема Дуглас Сполдінг, його брат Том,Еліс, Джейн та інші. Так, Дуглас постає на сторінках твору як спостережливий, чутливий, допитливий, емоційно рухливий хлопець. Психологізація образу головного персонажа реалізується через яскраві портретні характеристики:«Темним волоссямграєвітерець - то вправо відкине, то вліво. А на руках здаєтьсязалишилослід усе місто, на них пил доріг і кора дерев,пальці пахнуть виноградом,нестиглимияблуками і старими монетами. Вуха просвічуються на сонці, вони теплі і рожеві, ніби воскові персики, i, прозоре у повітрі, пахне м'ятою його дихання» [Бредбері 1988: 400]. Усі портретні деталі зорієнтовані на синкретизм відношення між ним і довкіллям і служать основою для детального та багато гранного розкриття людського характеру. Актуалізація в наведеному уривку сугестивних образів («пальці пахнуть виноградом, нестиглими яблуками і старими монетами», «пахне м'ятою його дихання», «вуха $<\ldots>$ ніби воскові персики») виконує акцентуальну функцію, підкреслюючи значимість у природі кожного елемента, їх рівноцінність і в той же час неповторність, виділяє нерозривні внутрішні зв'язки елементів навколишнього світу, де нічого не виникає нізвідки, а лише перероджується з однієї субстанції в іншу. Світ і людинатут постають не окремо існуючими субстанціями, а такими, що постійно перетинаються, зливаються, перетікають одна в одну. Автор вдається до аналізу через ремінісценцію, що $з$ одного боку окреслює своєрідність дитячого світобачення, а 3 іншого - формування в дитини образного мислення, масштабності світовідчуття, взаємозв' язків явищ навколишньогосвіту.

Митець звертає увагу на взаємозалежність природи та настрою персонажа, навіть його фізичного стану. Так, описуючи хворобливий стан Дугласа, митець зображує модель світу, яка зазнає таких самих руйнівних змін, як і організм дитини: «<..> >угрнутий 
y непроглядний червоний дим, Дуглас лежав і слухав, як глухо ухкає його серче, $i$ як повільно, поштовхами тече кров по його руках i ногах. Губи тяжкі, нерухливі. I думки також тяжкі і нерухливі, падають повільно і рідко одна за одною, ніби піщинки у лінивому пісочному годиннику» [Бредбері 1988: 510]. У наведених рядках простежується акцентування на уповільненні руху, дисгармонія (у нашому випадку - це хвороба хлопчика) виражається в заміні динаміки статикою в наступних метафоричних сполученнях: «думки тяжкі і нерухливі», «думки падають повільно», «думки падають рідко» тощо.

Дуглас є обдарованою дитиною, у якої розвинута уява і творче мислення. Окрім фантазійних образів у творі, які вигадує сам головний персонаж, існує цілісна фантазійна система, де Дуглас є центром і здатен впливати на перебіг подій, переміщаючись із реально існуючого світу у світ фантазії й дитячої мрії, балансуючи на межі реального й ірреального: «Стоячи у темряві біля відкритого вікна, він набрав повні груди повітря та щосили дмухнув. Вуличні ліхтарі миттю згасли, ніби цвіркуни на чорному полотні. Дуглас дмухнув ще раз, і в небі почали гаснути зірки» [Бредбері 1988: 407]. У свідомості хлопчика вибудувалося уявлення про здатність впливати на світ, хоча він розуміє, що ці зміни реалізуються лише в його уяві. При цьому, автор описує процес бісоціації, при якому, на відміну від асоціації, відбувається своєрідне переструктурування досвіду і творення нових реалій: «Керуючи своїм оркестром, Дуглас простягнув руку до сходу. I зійшло соние. Дуглас схрестив руки і посміхнувся, ніби справжній чарівник» [Бредбері 1988: 399].

Хлопчик уважно спостерігає за життям, що його оточує, i робить висновки іноді дуже дорослі, філософськи-значущі. Наприклад, розглядаючи межу між містом і природою, у вигляді яру щопідступає до нього, Дуглас помічає: «Із року в рік людина забирає щуось у природи, а природа знову бере своє, $і$ ніколи місто посправжньому не перемагає, воно постійно в небезпеці; воно візьме косилку, величезні ножиці, місто підрізає кущі, обприскує отру- 
тами шкідників, місто уперто пливе вперед, доки йому наказує циивілізація, але кожний дім от-от захлисне зелена хвиля $і$ сховає назавжди, а коли-небудь з лиия землі щеезне остання людина, $і$ його ножиці і садові лопати перетворюються у прах» [Бредбері 1988: 499]. Персоніфікований образ міста має агресивно-руйнівне забарвлення, перебуває у постійному двобої із «зеленою хвилею». Наповнюючись новим емоційно-смисловим змістом, урбаністична дійсність хоча й привносить у навколишне зриму унормованість і явний порядок, але попри це вичавлює, мабуть, найголовніше життя, творче начало, здатність до імпровізації.

Ця ж думка розгортається в епізоді протистояння бабусі Дугласа і тітки Роуз. У творчому хаосі бабусиної кухні завжди народжувалося чудо, черговий кулінарний шедевр, який приносив радість і не піддавався розкодуванню: «Обдавало то жаром пекельного вогню, то несподіваною хуртовиною иукрової пудри, і в цььому унікальному кліматі творила бабуся, $і$ погляд ї̈ очей був загадковий, ніби всі скарби Індії. Тисячорука, ніби індійська богиня, вона щзось взбивала, змішувала, поливала жиром, розбивала, кришила, різала, солила, перемімувала» [Бредбері 1988: 550]. Спроба тітки Роуз внести зміни в цей унікальний процес не призвела ні до чого доброго: «цілий тиждень сумних сніданків, безрадісних обідів і жалобних вечер» [Бредбері 1988: 527]. I тільки завдяки втручанню Дугласа і повернення кухні до первісного дитинного хаосу в будинку знов «легенький протяг поніс по коридорах смаковиті пахощіџ [Бредбері 1988: 529].

Осягаючи буття, спостерігаючи за щоденним життям мешканців містечка, переживаючи різні психологічні стани, навіть потрясіння («я був у самій гущі подій»), Дуглас вивчає самого себе. Одним із яскравихмоментівпідлітковоїсамоусвідомленості й самовизначення можна побачити увідчутті себе живим. Процес дорослішання бере відлік із моменту його самоусвідомлення як частини живого світу. Дуглас розуміє, що це приходить зі здатністю «помічати»життя. У повісті такі миті постають через призму споглядання якоїсьнезначної, на перший погляд, життєвої деталі, 
яка розширює свідомість, органічно розростається до символу загальнолюдських цінностей: «Ніби величезна зіниця ока, яке такожтількищовідкрилася $і$ дивиться з подивом, на нього дивиться весь світ. I тут вінзрозумів: ось щзо несподівано прийшло до нього, $i$ залишиться з ним назавжди, і вже ніколи не покине. Я ЖИВИЙ, подумав він» [Бредбері 1988: 333]. Цепочуття є ніби реальним почуттям дитини, яка себе ідентифікує, але одночасноце є чимось фантазійним і нереальним. Оскільки Дуглас потім відчуває усі запахи, чує абсолютно всі звуки, «як і накинулися на нього усі разом, і накрили його» [Бредбері 1988: 335], йде «наче сп'янілий від усіх ичих кольорів лісу» [Бредбері 1988: 335].

Предметною складовою концепту «дитинство» є номінативний образ: «Кульбабове вино - спіймане $і$ закупорене в пляики ліmо» [Бредбері 1988: 442]. Образ кульбабового вина багатоплановий. Поступово у творі він розгортається в символ. 3 одного боку предметна основа цього образу-символу цілком матеріальна - це справжнє вино. Але наддалі у своєму розвитку, як відмічають Т.Денисова та Г.Сиваченко, «ией образ ускладнюєтьсятим, щуо поступово починає абстрагуватися, від сторонятися, розростатися все далі і далі, відходячи від своєї матеріальної основи, проте не пориваючи з нею, а поглиблюючи ї смислову перспективу» [Денисова 1998: 71]. Можна додати, що воно щей цілющі ліки, i основа сімейного ритуалу, який об'єднує членів роду.

М.Кисельова відносить до символіки вина ще і «єдність $i$ гармонію відразу декількох протилежностей: природного і людського, буденного і священного, «мого» $i$ «твого», радісного і сумного, локального $і$ безкрайнього, миттєвого $і$ вічного» [Кисилева 1993: 16]. Кульбабове вино - це також своєрідний конденсат родового досвіду, який передається й у спогадахпро дитинство: «Це ж треба, - сказав Том. - Отак зберегти і червень, $і$ липень, і серпень. Чудово придумано»[Бредбері 1988: 453].

Дитинство у Р. Бредбері певною мірою жорстоке, божиття для нього - це безмежне «сьогодні». Діти не виокремлюють себе в 
потоці часу. Скажімо, Еліс, Джейн і Том не можуть повірити в те, що місіс Бентлі теж колись була дівчинкою із золотим волоссям, грала в «класи», і що вони колись стануть такими ж, як ця стара. Та якщо в серці літньої людини зберігся маленький острівець дитячого здивування перед світом, відчуття дива, то прірва між поколіннями може зникнути, а в душі відновиться гармонія. «Ще ніхто ніколи не сумнівався, щзо свого часу і я була дівчинкою. Це ж така жахлива дурниия! Я зовсім не журюся тим, щзо я стара,справді ні, - але позбавити мене дитинства нікому не дозволю!»обурено вигукує жінка [Бредбері 1988: 385]. Однак «дитинство» для міссБентлі зосереджується в межах речовинного світу. Гребінець, стара фотокартка, персник, старі театральні програми, квитки - усе це зрештою втрачає для неї сенс. Жінці вдається усвідомити, що варто жити сьогоднішнім днем, радіти й сумувати, вона вирішує: «надалі буду тільки самою собою, теперішньою, а не з якихось інших літ» [Бредбері 1988: 390].

Таким чином, складовими художнього концепту «дитинство» $\epsilon, 3$ одного боку, образи, що апелюють до реального світу, 3 іншого фантазійні образи, як своєрідний маркер «дитинності»,створені в уяві оповідача. Головну нитку проблематики твору, що розкривається через сприйняття дитини, поступове осягненняосновних проблем людського існування, становить боротьба добра зі злом, життя зі смертю, творчого руху й пасивної статичності.

\section{БІБЛІОГРАФІЯ}

Коситов 2012 - Коситов Н. С. Концепт «любовь» в системе нравственноэстетических ценностей В. В. Маяковского [Електрон. ресурс]/ Н.С.Коситов. Режим доступу: http://sibac.info/index.php/2009-07-01-10-21-16/2867. Бредбері 1988 - БредберіР. Марсіанські хроніки/ Рей Бредбері. - К. : Дніпро, 1988. 592 c. - C. 325-535.

Рыбкин 1989 - Рыбкин Р. Послесловие / Р.Рыбкин // Брэдбери Р. Вино изодуванчиков. Повесть и рассказы. - М. «Художественнаялітература», 1989. - 400с Денисова 1998 - Денисова Т. Зарубіжна література XX століття: [посібник для 11 класу] / Т.Денисова, Г.Сиваченко. - К., 1998. - С.69-71.

Киселева М.И. Творчество Рэя Брэдбери. Традиция и современный литературный контекст: автореф. дис. на соиск. учён.степ. канд. филол. наук: 10.01 .05 /

М.И.Киселева. - Нижний Новгород, 1993. - 17 с.

Стаття надійшла 28 жовтня 2013 р. 